\title{
UPAYA MENCEGAH DAN MEMINIMALKAN RESIKO DAN HAZARD \\ PADA TAHAP IMPLEMENTASI ASUHAN KEPERAWATAN BESERTA \\ CONTOH KASUS
}

\section{Dewi Meylinta Sembiring Dewimeylinta7@gmail.com}

\section{LATAR BELAKANG}

Setiap pekerjaan di dunia ini pasti masing-masing memiliki tingkat risiko bahaya. Keselamatan dan Kesehatan Kerja (K3) merupakan suatu upaya untuk menciptakan suasana bekerja yang aman, nyaman, dan tujuan akhirnya adalah mencapai produktivitas setinggitingginya. Keselamatan dan Kesehatan Kerja sebagai suatu program didasari pendekatan ilmiah dalam upaya mencegah atau memperkecil terjadinya bahaya (hazard) dan risiko (risk) terjadinya penyakit dan kecelakaan, maupun kerugian-kerugian lainya yang mungkin terjadi.

Diperkirakan bahwa setiap tahun terjadi 270 juta kecelakaan-kecelakaan yang akibat kerja yang tidak fatal (setiap kecelakaan paling sedikit mengakibatkan paling sedikit tiga hari absen dari pekerjaan) dan 160 juta penyakit-penyakit baru akibat kerja. Terjadinya kecelakaan kerja tentu saja menjadikan masalah yang besar bagi kelangsungan suatu usaha. Kerugian yang diderita tidak hanya berupa kerugian materi yang cukup besar namun lebih dari itu adalah timbulnya korban jiwa yang tidak sedikit jumlanya. Kehilangan sumber daya manusia ini merupakan kerugian yang sangat besar karena manusia adalah satu-satunya sumber daya yang tidak dapat digantikan oleh teknologi apapun.

Maka dari itu Pelaksanaan K3 akan mewujudkan perlindungan terhadap tenaga kerja dari risiko kecelakaan kerja dan penyakit akibat kerja yang dapat terjadi pada waktu melakukan pekerjaan di tempat kerja. Dengan dilaksanakannya perlindungan K3, diharapkan akan tercipta tempat kerja yang aman, nyaman, sehat dan tenaga kerja yang produktif, sehingga akan meningkatkan produktivitas kerja dan produktivitas perusahaan. Dan K3 mutlak untuk dilaksanakan pada setiap jenis bidang pekerjaan tanpa kecuali. Dalam pelaksanaan K3 sangat dipengaruhi oleh tigafaktor utama yaitu manusia, bahan, dan metode yang digunakan.Ketiga unsur tersebut tidak dapat dipisahkan dalam mencapai penerapan K3 yang efektif dan efisien. 


\section{METODE}

Metode yang digunakan adalah metode kualitatif dan metode literature review, yaitu dengan mengumpulkan data, membaca, mengkaji dan menganalisis data tersebut dari berbagai sumber seperti buku teks, e-book,jurnal,buku referensi yang berhubungan dengan tema yaitu Konsep dasar K3 : Sehat, kesehatan kerja, risiko dan hazard dalam asuhan keperawatan. Dan disini saya akan lebih membahas mengenai risiko dan hazard dalam keperawatan. Literature yang digunakan adalah sebanyak 11 dari berbagai sumber dengan ketentuan tahun terbit terakhir adalah tahun 2012 atau paling lama diterbitkan 8 tahun terakhir.

\section{HASIL}

Hazard adalah sesuatu yang menimbulkan kerugian, kerugian ini meliputi pada gangguan kesehatan dan cidera, hilangnya waktu kerja, kerusakan pada property, area atau tempat kerja, produk atau lingkungan, kerugian pada proses produksi ataupun kerusakan - kerusakan lainnya. Firence (1978) mendefinisikan hazard sebagai suatu material atau kondisi yang berpotensi ditempat kerja dimana dengan atau tanpa interaksi dengan variabel lain dapat menyebabkan kematian, cedera, atau kerugian lain.

Kata risiko (Risk) berasal dari bahasa Arab yaitu Rizk yang berarti pemberian. Menurut kamus Webster, risiko adalah kemungkinan timbulnya kerugian cedera, keadaan yang merugikan atau perusakan (Risk is Possibility of loss, injury,disadventage or destruction). MenurutInternational Labour Organization (ILO), risiko adalah kemungkinan adanya peristiwa atau kecelakaan yang tidak diharapkan dan dapat terjadi dalam waktu dan keadaan tertentu. Sumber lain menyatakan bahwa risiko adalah adalah ukuran kemungkinan kerugian yang timbul dari sumber bahaya (hazard) tertentu yang terjadi, dengan kata lain risiko adalah probabilitas kerusakan atau kerugian dari hazard yang melekat pada spesifik individu atau kelompok yang terpapar oleh hazard tersebut. Risiko merupakan akumulasi dari potensi hazard, konsekuensi

yang diakibatkannya, durasi pemaparan dan probabilitas yang ditimbulkannya. Risiko merupakan gambaran kuantitatif dari kemungkinan kerugian yang mempertimbangkan kemungkinan suatu hazard yang akan mengakibatkan suatu peristiwa tersebut. 
Fungsi dan tugas perawat dalam usaha keselamatan dan kesehatan kerja (K3) adalah sebagai berikut : A. Fungsi perawat : Mengkaji masalah kesehatan, Menyusun rencana asuhan keperawatan pekerja, Melaksanakan pelayanan kesehatan dan keperawatan terhadap pekerja, Melakukan penilaian terhadap asuhan keperawatan yang dilakukan. B. Sedangkan tugas perawat dalam usaha keselamatan dan kesehatan kerja adalah : Mengawasi lingkungan pekerja, Memelihara fasilitas kesehatan perusahaan, Membantu dokter dalam pemeriksaan kesehatan pekerja, Membantu melakukan penilaian terhadap keadaan kesehatan pekerja, Merencanakan dan melaksanakan kunjungan rumah dan perawatan di rumah kepada pekerja dan keluarga yang mempunyai masalah kesehatan, Ikut berperan dalam penyelenggaraan pendidikan K3 terhadap pekerja, Ikut berperan dalam usaha keselamatan kerja, Membantu usaha penyelidikan kesehatan

pekerja, Mengkoordinasi dan mengawasi pelaksanaan K3. Lalu bagaimana Upaya Mencegah Dan Meminimalkan Risiko Dan Hazard Pada Tahap Implementasi Asuhan Keperawatan? Berikut penjelasannya akan dibahas di bagian pembahasan.

\section{PEMBAHASAN}

Implementasi keperawatan adalah serangkaian kegiatan yang dilakukan oleh perawat untuk membantu klien dari masalah status kesehatan yang dihadapi kestatus kesehatan yang lebih baik yang menggambarkan kriteria hasil yang diharapkan. Implementasi merupakan inisiatif dari rencana tindakan untuk mencapai tujuan yang spesifik. Tahap pelaksanaan dimulai setelah rencana tindakan disusun dan ditujukan pada nursing orders untuk membantu klien mencapai tujuan yang diharapkan.. Tujuan dari pelaksanaan adalah membantu klien dalam mencapai tujuan yang telah ditetapkan, yang mencakup peningkatan kesehatan, pencegahan, penyakit, pemulihan kesehatan dan memfasilitasi koping. Untuk kesuksesan pelaksanaan implementasi keperawatan agar sesuai dengan rencana keperawatan, perawat harus mempunyai kemampuan kognitif (intelektual), kemampuan dalam hubungan interpersonal, dan keterampilan dalam melakukan tindakan. Nah, dalam implementasi ini juga terdapat risiko dan hazard.

Contoh upaya mencegah Hazard dan Risiko Implementasi Keperawatan :

- Membantu dalam aktifitas sehari-hari

- Konseling

- Memberikan asuhan keperawatan langsung.

- Kompensasi untun reaksi yang merugikan. 
- Teknik tepat dalam memberikan perawatan dan menyiapkan klien utnuk prosedur.

- Mencapai tujuan perawatan mengawasi dan menggevaluasi kerja dari anggota staf lain.

Tiga prinsip pedoman implementasi asuhan keperawatan :

- Mempertahankan keamanan klien

- Memberikan asuhan yang efektif

- Memberikan asuhan yang seefisien mungkin

Upaya Pencegahan Kecelakaan Kerja Sama Secara Umum yaitu :

- Upaya pencegahan kecelakaan kerja melalui pengendalian bahaya yang di tempat kerja yaitu dengan pemantauan dan pengendalian kondisi tidak aman di tempat kerja.

- Upaya pencegahan kecelakaan kerja melalui pembinaan dan pengawasan pelatihan dan pendidikan,konseling dan konsultasi,pengembangan sumber daya atau teknologi terhadap tenaga kerja tentang penerapan $\mathrm{k} 3$.

- Upaya pencegahan kecelakaan kerja melalui system manajemen prosedur dan aturan k3, penyediaan sarana dan prasarana $\mathrm{k} 3$ dan pendukungnya, penghargaan dan sanksi terhadap penerapan $\mathrm{k} 3$ di tempat kerja.

Terdapat Juga Beberapa Upaya Pencegahan Lain, Antara Lain :

Pelayanan kesehatan kerja diselenggarakan secara paripurna,terdiri dari pelayanan promotif,prefentif,kuratif dan rehabilitative yang di laksanakan dalam suau system yang terpadu.

\section{BERIKUT ADALAH CONTOH KASUS :}

Seorang perawat di RSUD Gunung Jati, kota Cirebon, diketahui positf difteri pasca menangani pasien yang menderita penyakit yang sama. CIREBON - seorang perawat di RSUD Gunung Jati,kota Cirebon, diketahui positif difteri pasca menangani pasien difteri. Berdasarkan informasi, perawat tersebut diduga tertular pasca menangani dan melakukan tindakan awal pada pasien positif difteri tersebut, perawat terkena diffteri berinisal Ru dan bertugas di ruang Instalasi Gawat Darurat (IGD) RSUD Gunung Jati. Ru diketahui merupakan perawat pertama difteri yang masuk rumah sakit tersebut.

Analisa Kasus 1 
Hazard yang ada di kasus : Hazard biologis yaitu perawat tertular penyakit difteri dari pasien pasca menangani dan melakukan tindakan awal pada pasien positif difteri.

Upaya pencegahan kasus 1

- Upaya pencegahan dari rumah sakit /tempat kerja

- $\quad$ RS menyediakan APD yang lengkap sepeti masker, handskoon, dan scout dll.

Alasan : meminimalisir terjadinya atau tertularnya penyakit / infeksi yang dapat terjadi terutama saat bekerja, APD harus selalu di gunakan sebagai perlindungan diri dengan kasus di atas dapat di hindari jika perawat menggunakan APD lengkap mengingat cara penularan difteri melalui terpaparnya cairan ke pasien.

- Menyediakan sarana untuk mencui tangan atau alkohol gliserin untuk perawat.

Alasan : cuci tangan merupakan cara penanganan awal jika kita sudah terlanjur terpapar cairan pasien baik pasien beresiko menularkan atau tidak menularkan. Cuci tangan merupakan tindakan aseptic awalawal sebelum ke pasien maupun setelah ke pasien.

- RS menyediakan pemilahan tempat sampah medis dan non medis.

Alasan : bila sampah medis dan non medis tercampur dan di kelola dengan baik akan menimbulkan penyebaran penyakit.

- $\quad$ RS menyediakan SOP untuk tindakan keperawatan.

Alasan : agar petugas/perawat menjaga konsisten dan tingkat kinerja petugas/perawat atau timdalam organisasi atau unit kerja, sebagai acuan ( chek list ) dalam pelaksanaan kegiaan tertentu bagi sesama pekerja. Supervisor dan lain-lain dan SOP merupakan salah satu cara atau parameter dalam meningkatkan mutu pelayanan.

Upaya pecegahan pada perawat :

- Menjaga diri dari infeksi dengan mempertahankan teknik aseptic seperti mencuci tangan, memakai APD, dan menggunakan alat kesehatan dalam keadaan 
Alasan : agar perawat tidak tertular penyakit dari pasien yang di tangani meskipun pasien dari UGD dan memakai APD adalah salah satu SOP RS.

- Perawat mematuhi standar Operatinal Prosedure yang sudah ada RS dan berhati-hati atau jangan berburu-buru dalam melakukan tindakan.

Alasan : meskipun pasien di ruang UGD dan pertama masuk RS, perawat sebaiknya lebih berhati-hati atau jangan terburu-buru dalam melakukan tindakan ke pasien dan perawat menciptakan dan menjaga keselamatan tempat kerja supaya dalam tindakan perawat terhindar dari tertularnya penyakit dari pasien dan pasien juga merasa aman.

\section{PENUTUP}

Kesimpulan

Keselamatan dan Kesehatan Kerja merupakan suatu program didasari pendekatan ilmiah dalam upaya mencegah atau memperkecil terjadinya bahaya (hazard) dan risiko (risk) terjadinya penyakit dan kecelakaan, maupun kerugian-kerugian lainya yang mungkin terjadi. Hazardadalah sesuatu yang menimbulkan kerugian, kerugian ini meliputi pada gangguan kesehatan dan cidera, hilangnya waktu kerja, kerusakan pada property, area atau tempat kerja, produk atau lingkungan, kerugian pada proses produksi ataupun kerusakan - kerusakan lainnya. Berdasarkan karakteristik dampak yang diakibatkan oleh suatu jenis bahaya maka jenis bahaya dapat dikelompokan menjadi 2 yaitu bahaya kesehatan kerja dan bahaya keselamatan kerja

Sedangkan Resiko adalah ukuran kemungkinan kerugian yang timbul dari sumber bahaya (hazard) tertentu yang terjadi. Menurut Kolluru (1996) ada 5 macam tipe risiko, yaitu: risiko keselamatan, risiko kesehatan, risiko lingkungan dan ekologi, risiko finansial, danrisiko terhadap masyarakat. 


\section{DAFTAR PUSTAKA}

Firawati.(2012). Pelaksanaan Program Keselamatan Pasien di RSUD Solok. Jurnal Keselamatan Pasien, 6(2), 74-77.

Indragiri, Suzana.,Triesda Yuttya.2018.Manajemen Risiko K3 Menggunakan Hazard Identification Risk Assement and Risk Control (HIRARC). Jurnal Kesehatan 9 (1), 54-60

Irawan,Shandy.,dkk.20 15.Penyusunan Hazard Identification Risk Assesment and Risk Control (HIRARC). Di PT. X. Jurnal Titra 3 (1), 110-117

Prasetyo, Erwan Henri.,dkk.2018. Analisis Hira (Hazard identification and risk assessment) pada instansi x di Semarang.Jurnal Kesehatan masyarakat 6 (5), 45-58.

Ramadhan, F. (2017). Analisis Kesehatan dan Keselamatan Kerja (K3) Menggunakan Metode Hazard Identification Risk Assessment and Risk Control (HIRARC). Jurnal Seminar Nasional Riset Terapan 10 (5), 164-169.

Ramdan,Iwan M.,dkk.2017. Analisi Risiko Kesehatan Dan Keselamatan Kerja (K3) Pada Perawat.Jurnal Kesehatan 5 (3), 97-110.

Restuputri, D. P. (2015). Analisis Kecelakaan Kerja Dengan Menggunakan Metode Hazard and Operability Study (HAZOP). Jurnal Ilmiah Teknik Industri, 14(1), 77-87

Simamora, R. H. (2011). ROLE CONFLICT OF NURSE RELATIONSHIP WITH PERFORMANCE IN THE EMERGENCY UNIT OF HOSPITALS RSD DR. SOEBANDI JEMBER. The Malaysian Journal of Nursing, 3(2), 23-32.

Suhariono.(2019). Pengelolaan Keselamatan dan Kesehatan Kerja (K3) Dirumah Sakit. Jawa Timur : Uwais Inspirasi Indonesia

Wardhani, V. (2017). Buku Ajar Manajemen Keselamatan Pasien. Malang: UB Press 